

\section{DISCLAIMER}

This report was prepared as an account of work sponsored by an agency of the United States Government. Neither the United States Government nor any agency Thereof, nor any of their employees, makes any warranty, express or implied, or assumes any legal liability or responsibility for the accuracy, completeness, or usefulness of any information, apparatus, product, or process disclosed, or represents that its use would not infringe privately owned rights. Reference herein to any specific commercial product, process, or service by trade name, trademark, manufacturer, or otherwise does not necessarily constitute or imply its endorsement, recommendation, or favoring by the United States Government or any agency thereof. The views and opinions of authors expressed herein do not necessarily state or reflect those of the United States Government or any agency thereof. 


\section{DISCLAIMER}

Portions of this document may be illegible in electronic image products. Images are produced from the best available original document. 
The facilities of Argonne National Laboratory are owned by the United States Government. Under the terms of a contract (W-31-109-Eng-38) between the U. S. Energy Research and Development Administration, Argonne Universities Association and The University of Chicago, the University employs the staff and operates the Laboratory in accordance with policies and programs formulated, approved and reviewed by the Association.

\section{MEMBERS OF ARGONNE UNIVERSITIES ASSOCIATION}

The University of Arizona Carnegie-Mellon University Case Western Reserve University The University of Chicago University of Cincinnati Illinois Institute of Technology University of Illinois Indiana University Iowa State University The University of Iowa
Kansas State University The University of Kansas Loyola University Marquette University Michigan State University The University of Michigan University of Minnesuta University of Missouri Northwestern University University of Notre Dame
The Ohio State University

Ohio University

The Pennsylvania State University

Purdue University

Saint Louis University

Southern Illinois University The University of Texas at Austin Washington University Wayne State University The University of Wisconsin

\section{NOTICE}

This report was prepared as an account of work sponsored by the United States Government. Neither the United States nor the United States Energy Research and Development Administration, nor any of their employees, nor any of their contractors, subcontractors, or their employees, makes any warranty, express or implied, or assumes any legal liability or responsibility for the accuracy, completeness or usefulness of any information, apparatus, product or process disclosed, or represents that its use would not infringe privately-owned rights. Mention of commercial products, their manufacturers, or their suppliers in this publication dues not imply or connote approval or disapproval of the product by Argonne National Laboratory or the U. S. Energy Research and Development Administration. 


\title{
THE EBR-II STEAM PLANT: OPERATING EXPERIENCE \\ AND PERFORMANCE EVALUATION
}

by

H. W. Buschman

EBR-II Project

Argonne National Laboratory

Argonne, Illinois - Idaho Falls, Idaho.

September 1974

\begin{abstract}
This report was prepared as an account of work sponsored by the United States Government. Neither the United States nor the United. States Energy Research and Development Administration, nor any of their employees, nor any of their contractors, subcontractors, or their employees, makes any warranty, expreec or implicd, or assumes any legil liability or responsibility for the accuracy, completeness or usefulness of any information, apparatus, product or process disclosed, or represents that its use would not infringe privately owned rights.
\end{abstract}


TABLE OF CONTENTS

$\underline{\text { Page }}$

ABSTRACT. . . . . . . . . . . . . . . . . . . . . . . 3

I. INTRODUCTION . . . . . . . . . . . . . . . . . . 3

II. STEAM CYCLE. . . . . . . . . . . . . . . . . . . 4

III. OPERATING EXPERIENCE . . . . . . . . . . . . . . . . . . 7

A. Control Valves . . . . . . . . . . . . . . . 7

1. Large Steam-bypass Valve . . . . . . . . . . . . . . 7

2. 1250/150-psig Pressure-reducing Valve. . . . . . . . 8

3. Control Valves for Feedwater-pump Recirculation. . . . . 9

B. Relief Valves. . . . . . . . . . . . . . 10

1. Pressurmatic Vent Valve. . . . . . . . . . . . 10

C. Pumps. . . . . . . . . . . . . . . . . . . . 11

1. Condensate Pump. . . . . . . . . . . . . . . . . . 11

2. Feedwater Pump . . . . . . . . . . . . . . 12

D. Blowdown System. . . . . . . . . . . . . . . . 12

E. Heat-exchanger Tubes . . . . . . . . . . . . . . . 13

1. Main Condenser . . . . . . . . . . . . . . 13

2. No. 1 Feedwater Heater . . . . . . . . . . . . 14

F. Piping for 150-psig Steam. . . . . . . . . . . . . . 15

IV. FUTURE IMPROVEMENTS. . . . . . . . . . . . . . . 16

v. CONCLUSIONS. . . . . . . . . . . . . . . . . . 17

FIGURE

1. EBR-II Steam Cycle . . . . . , , , . . . . . . . . 5 
THE EBR-II STEAM PLANT: OPERATING EXPERIENCE

AND PERFORMANCE EVALUATION*

by

H. W. Buschman

ABSTRACT

Operating experience with the EBR-II steam plant has been very good, and it shows that no unusual problems are associated with operating and maintaining a steam plant that has an LMFBR as the energy source. Problems that occurred and were corrected were with: control valves, pumps, weld joints, and heat-exchanger tubes. An active program of surveillance and maintenance is required to maintain high availability. Modifying the plant to use newly developed equipment is most important in solving operational problems. Usually these modifications simplify operation and improve plant factor.

\section{INTRODUCTION}

Initially EBR-II was built and operated to demonstrate the feasibility of economically producing electrical power from the heat generated from operation of an LMFBR. Since the original mission was accomplished, EBR-II has been operated as an irradiation test fac1lity.

The steam cycle of EBR-II operates at a relatively hIgh pressure and temperature with the primary purpose of safely and reliably dissipating the power generated by the nuclear reaction. It is essentially a conventional

\footnotetext{
* Mention of commercial products, their manufacturers, or their suppliers in this report does not imply or connote approval or disapproval of the product by the Argonne National Laboratory or the U. S. Atomic Energy Commission.
} 
steam plant, but it has special features to achieve high rellability. Modifications to the system have been made since initial operation to increase reliability, flexibility, and ease of operation and to reduce maintenance. The result has been that the steam plant has seldom been responsible for loss of plant availability. As of July 1974, the EBR-II turbine-generator had produced over $5000,000,000 \mathrm{kWh}$ of electrical energy.

\section{STEAM CYCLE}

Figure 1 shows a simplified diagram of the EBR-II steam cycle. Steam flows from the steam generator to either a condensing turbine or directly to the condenser; the choice depends on the desired mode of operation. The condensate is pumped from the condenser hot well through air ejectors, a blowdown cooler, and No. 1 feedwater heater to the deaerator (No. 2 feedwater heater). Water from here is pumped by a feedwater pump through No. 3 and No. 4 feedwater heaters to the steam drum.

EBR-II normally operates with continuous boiler blowdown of 20,000 lb/hr. The blowdown flow first enters a high-pressure flash tank controlled at 700 psig. The flashed steam is routed to feedwater heater No. 3, and the condensate is routed to the low-pressure flash tank, which operates at 50 psig. The flashed steam from this tank is routed to feedwater heater No. 1 , and the condensate flows into a blowdown cooler. The flow from the cooler flows through an aftercooler and blowdown demineralizers and then is returned to the condenser hot well.

The steam system may be operated with total steam flow through the turbine or any percentage up to $100 \%$ bypassed directly to the condenser. Normal operation is with full flow passing through the turbine and generator output in parallel with off-site power. In this mode, steam flow to the turbine is controlled by the Initial Pressure Regulator (IPR). The IPR senses the main steam-header pressure and controls the steam flow as necessary to maintain pressure at 1250 psig.

The generator output may be separated from the INEL (Idaho National Engineering Laboratory) loop and used to supply only EBR-II site loads. The 


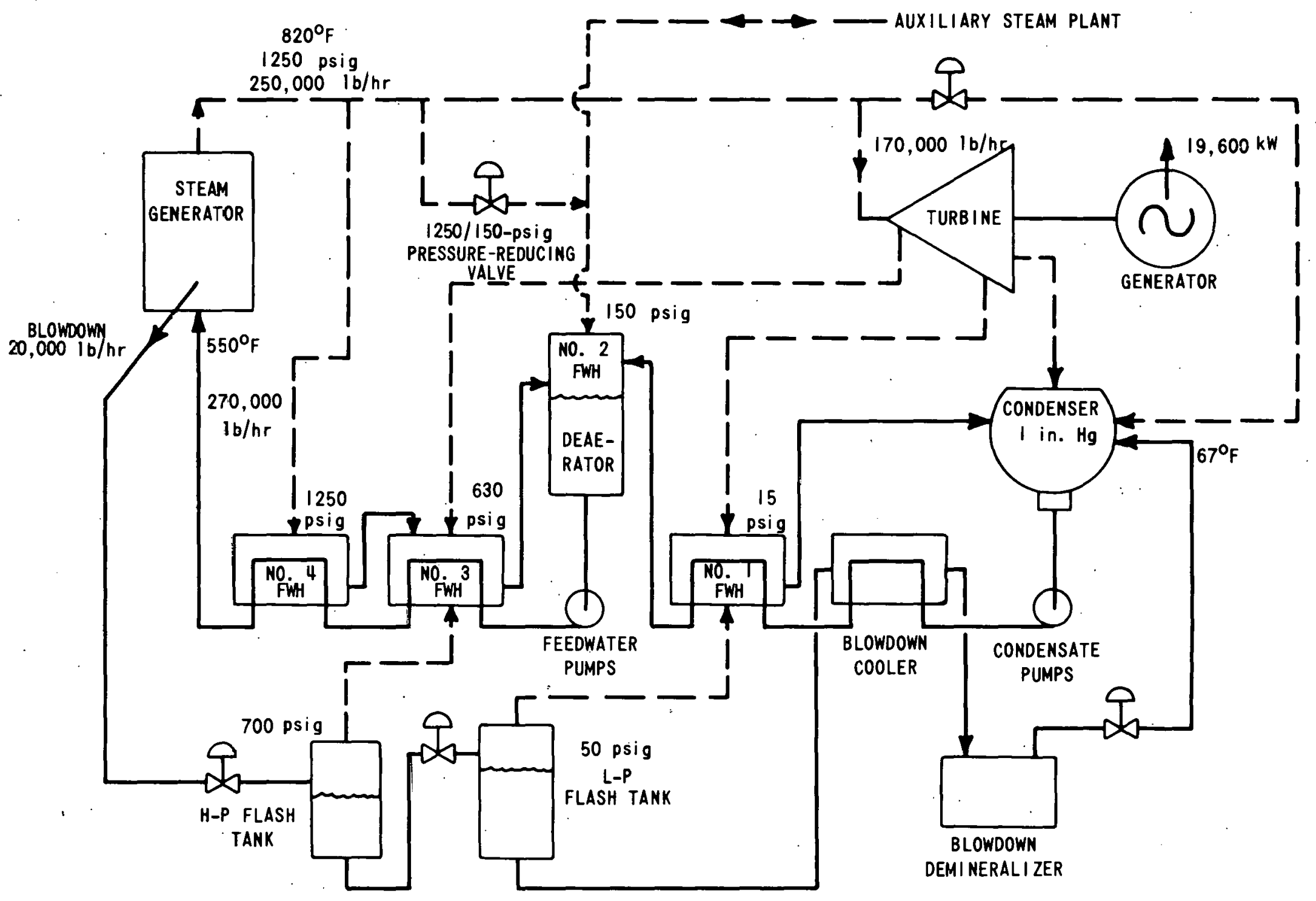

Fig. 1. EBR-II Steam Cycle 
speed governor controls the main turbine when it is operating separated from the INEL 10op. Because the EBR-II site load (about $5 \mathrm{MWe}$ ) is less than the generator output when the turbine uses all the available steam with the reactor at $62.5 \mathrm{MWt}$, the excess steam is routed directly to the condenser. This feature permits the reactor to be operated at full power independently of an outside power source.

Load-1imit control is the third device by which the main turbine is controlled. This method is normally used only for turbine startup and generator loading and unloading. However, it can be used when the generator is parallel with the INEL loop to vary the percentage of steam bypassed to the condenser. This mode of control has been used when the IPR had to be removed from service because of malfunction or need for maintenance.

Two pumps are available to pump condensate from the condenser hotwell. There are three installed feedwater pumps: a positive-displacement startup pump for use at low power ( $<10 \mathrm{MWt}$ ); feedwater pump No. 1 (rated at 295,000 $1 \mathrm{~b} / \mathrm{hr}$ ), driven by an 800-hp motor; and feedwater pump No. 2 (rated at 388,600 $\mathrm{lb} / \mathrm{hr}$ ), driven by a 1000-hp motor. Either pump, No. 1 or 2 , has enough capacity to supply plant demand for feedwater at full power. The two main pumps are so installed that simultaneous operation is not possible. The operating pump, however, may be changed by firststopping the pump that is operating and then starting the standby unit.

Feedwater heaters No. 1, 3, and 4 are shell-and-tube type, with water flowing through the tube side and steam on the shell side. Heaters No. 1 and 3 normally recelve their heating steam from turbine extraction and steam flashed from the blowdown-system flash tanks. Heater No. 4 receives heating steam directly from the main steam header. When extraction steam is not available from the turbine, steam is also supplied to the No. 3 heater from the main steam header at 200 psig by a control valve.

No. 2 feedwater heater is a vertical, deaerating, direct-contact traytype heater. Heating steam is supplied from the main steam header to the heater at a constant pressure of 150 psig by a pressure-reducing valve. 
Steam may also be withdrawn from this supply to supplement the oil-fired, auxiliary-steam boilers.

\section{OPERATING EXPERIENCE}

As stated in the Introduction, the steam plant has seldom been responsible for loss of reactor-plant availability. Few difficulties have been experienced; those that have occurred have been conventional. A continual program of monitoring and modification is designed to solve problems with components before they significantly affect plant operation. These problems are discussed below.

\section{A. Control Valves}

Most operational problems probably have been with control valves. Factors most responsible were: high pressure drop, fluid flastiing, valve sized too large, and stem-force reversal.

\section{Large Steam-bypass Valve}

This valve is used to bypass (dump) steam directly to the condenser when the turbine is not operating or part of the steam generated is not routed to the turbine. The valve control system is designed to control automatically the main steam-header pressure at about 1250 psig. If the main turbine is tripped off the valve opens automatically to dump excess steam to the condenser.

Problems with this valve were originally twofold: (1) response was not fast enough to limit pressure of the main steam header to below the set point of safety valves during rapid reduction of turbine-steam demand; and (2) the valve had undesirable flow characteristics and was usually unstable. 
In September 1969, when the maximum power level of EBR-II was increased from 50 to $62.5 \mathrm{MWt}$, performance of this valve was found intolerable and action was taken to improve it. Replacement of the original pneumatic control system with a completely electrical system improved the response of the system so that the valve rapidly responded to changes in steam-header pressure and controlled the pressure within a very narrow band. This change in control system did not affect instability of the valve or poor control at low steam flows.

It was concluded, after consultation with the valve vendor, that the instability of the double-port throttle plug was caused by a reversal of stem force. This reversal occurred when the valve was about $35-45 \%$ open, the opening necessary to bypass all the steam to the condenser when the reactor operates at 50-62.5 MWt. The valve actuator must reverse its action as the valve plug passes through its balance point. If the control point is near the plug balance point, the actuator w11l either under-or overshoot the control position because time is needed for the actuator to reverse its operation. When this sequence occurs, the process must repeat itself because either too little or too much steam is passing through the valve to control the correct steam-header pressure. Hence, the valve plug will oscillate within a region containing both the control point and the point of stem-force reversal. To eliminate this instability the original linear throttle was replaced with a V-pup plug. This plug has desirable control charactistics throughout its full range of travel. Since these changes, performance of this valve has been excellent.

\section{1250/150-psig Pressure-reducing Valve}

This valve is used to control the steam pressure in the No. 2 feedwater heater, the deaerator. The original valve was a double-port valve that was grossly oversize--it could pass about eight times the normal steam demand. Because of the double-port design and the high capacity of the 
valve, control was very difficult during plant startup and shutdown. Apparently, the flow and high pressure drop also tended to bow the plug, causing drag in the stem-post gulde bushings. This drag caused the valve to stick and not to function smoothly throughout its stroke. The poor pressure.control of the deaerator, which resulted from the characteristics of this valve, caused frequent actuation of the safety valves on the deaerator. Replacing the original valve with a single-port valve properly sized for the application solved these difficulties. Because reducing noise level in the power plant was also desirable, the new valve was chosen with low noise characteristics. The replacement, a valve of self-"drag" design, responds rapidly, has extremely fine control, shuts off tightly, and operates quietly.

\section{Contro1 Valves for Feedwater-pump Recirculation}

Originally neither main boiler feedwater pump had automaticrecirculation-control (ARC) systems. Both had an installed bypass line through which about $20 \%$ of the pump design flow was continuously recirculated to the deaerator regardless of the total feedwater flow. This continuous recirculation is a waste of pumping power and a needless reduction of the available pump output. With continuous-recirculation flow, the output of both pumps was barely adequate for 62.5-MWt operation.

On feedwater pump No. 1 (motor driven) this problem was solved by linstalling a valve that automatically controls recirculation.

Pump No. 2, the turbine-driven pump, was later replaced with a higher-capacity motor-driven pump. (See "Pumps"). The ARC valve for pump No. 1 automatically shuts of $\mathrm{fecirculation}$ flow of the pump after pump output is above the vendor's specified minimum flow. This change increases the design output of the pump about $20 \%$. The valve does the following: (a) prevents reverse flow through the pump; (b) protects the pump from overheating by permitting passage of a limited flow through the pump during periods of low flow; and (c) dissipates the energy in the high-pressure discharge for quiet, 
safe delivery to the deaerator.

An ARC' valve of identical design was installed on feedwater pump No. 2 when the turbine-driven pump was replaced by a motor-driven one.

\section{B. Relief Valves}

A review of the structural integrity of the safety valves installed in the high-pressure-steam system resulted in modifications that lowered the working stresses in these areas. This review was requested by the AEC as a result of reported structural fallures that occurred at other power plants. Several improvements in structural design greatly reduced the possibility of a steam-1ine rupture due to the reaction force of a blowing safety valve.

\section{Pressurmatic Vent Valve}

An electrically controlled, pilot-operated, relief valve was installed on the main steam header between the superheaters and the main steam stop valve. The primary purpose of the valve is to vent steam from the steamgenerating equipment if a water-to-sodium leak occurs. The valve may be actuated either manually by a control switch in the control room or automatically by high pressure in the steam header. Normally, valve operation is automatic and the valve is set to open at a pressure lower than that of the two steamdrum safety valves. Thus, in addition to its primary purpose, it reduces the duty cycle and maintenance of the two safety valves. This feature has been very important, because maintenance of these valves requires cooling the system and draining the secondary sodium system, which are time-consuming. Because this valve is in addition to the valves (ASME Code) on the steam drum, isolation valves were installed ahead of it to allow it to be serviced without shutting down the steam-generating equipment. The manual-control switch in the control room permits the valve to be operated independently of system 
pressure if the pressure is greater than $30 \mathrm{psig}$, a design 1imitation.

\section{Pumps}

The turbine-driven feedwater and condensate pumps originally installed have been replaced with motor-driven pumps. This replacement significantly improved operational reliability and flexibility. The motor-driven pumps were required for startup and operation up to a reactor power level of about $30 \mathrm{MWt}$ before the turbine pumps could be operated. Operation of the turbine-feedwater pump at a reactor power below $30 \mathrm{MWt}$ was not possible because the exhaust steam could not be dissipated from the turbine. The exhaust 150-psig steam was used for feedwater heating in the deaerator, with excess routed to the condenser. Below 30 MWt the steam demand of the deaerator was too low, in combination with the capacity of the connection to the condenser, to adequately dissipate the exhaust steam.

Replacement of the turbine pumps with motor-driven units provided backup pumping ability during all modes of reactor operation. This action was also prompted because the turbine-driven pumps were not available for operation much of the time owing to unscheduled maintenance.

\section{Condensate Pump}

The two installed condensate pumps are identical; originally one was motor-driven, the other turbine-driven. The turbine-driven pump could not be operated unless exhaust steam was available from the turbine-driven feedwater pump. Hence removing the turbine-driven pump required removing the condensate-pump turbine. Replacement of this turbine with a motor was relatively simple and Inexpensive. A simple modification of the base plate allowed mounting of the 150-hp motor in place of the turbine without disturbing the pump. Controls for the two pumps were modified so that one pump is in standby while the other pump is running. 


\section{Feedwater Pump}

The new motor-driven feedwater pump is a seven-stage centrifugal pump driven by a 1000-hp motor. The pump is similar to the other motor-driven pump except that its capacity is greater by about $30 \%$. Features of the modified installation are: (a) An automatic recirculation-control valve to control pump recirculation flow. (b) A valve to throttle flow for pump warmup. (c) A "drag" valve to control pump discharge pressure. (d) A vacuum-quench motor controller for selecting and starting either of the two motor-driven pumps.

The two feed pumps may not be operated simultaneously, and neither has an automatic start. Difficulty was experienced in obtaining satisfactory performance from the new pump--the pump balance drum was of improper size and the balance chamber had insufficient leakoff. The result of these deficiencies was improper axial pressure balance, which resulted in overloading the thrust bearing. After the vendor corrected the deficiencies, the new pump and system have performed satisfactorily. The newly installed discharge-control valve has proven to be capable of stable operation with extremely fine control.

\section{Blowdown System}

Piping downstream of the level-control valve for the high-presure flash tank, has undergone severe erosion from effects of flashing saturated steam. Upstream of the control valve, the water is saturated. Downstream of the valve,part of the water flashes to steam, greatly accelerating the remaining water. The water breaks up into droplets that strike the walls of the piping at very high speed. Most of the damage to the piping takes place in the region of flashing, where the droplets of water have the highest velocity normal to the piping axis. Damage also occurs where the direction of the flow stream changes, as at a pipe elbow. 
Sufficient erosion has occurred both in piping elbows and in the piping (also within the control valve) immediately adjacent to the control valve to completely penetrate the pipe wall. To minimize erosion, the following action was taken:

1. All changes in piping direction downstream of the control valve were eliminated.

2. An orifice with a replaceable stainless steel wear section was installed immediately downstream of the control valve.

These changes reduced flashing within the control valve, so that this valuable component is protected, and the flashing takes place.within a replaceable length of piping designed to be more resistant to erosion. Recent inspection of this piping showed that erosion is much reduced and that the valve is now protected.

\section{E. Heat-exchanger Tubes}

\section{Main Condenser}

A single-tube failure occurred in the main condenser in October 1971. The leak, which allowed condenser cooling water to leak into the condensate, was in the middle of a tube just opposite where recirculation flow from the condensate pumps enters the condenser. Some of this condensate flashes to steam as it enters the high-vacuum region within the condenser. This large change in specific volume causes the remaining water in the flow stream to be accelerated to great speeds. Some of the water impinged on the tube and caused failure. A flow baffle inside the condenser, designed to prevent this impingement, was not completely effective.

The tubes adfacent to the leaking one also were damaged. All damaged tubes were in the first row and apparently were acting as a shield for tubes behind them. The condenser was repaired by permanently plugging 11 
tubes in the area of erosion damage. The plugged tubes are expected to protect the rest of the tubes in that area from direct impingment of water. The number of tubes plugged was based on the number of plugs on hand. Plugging of 11 tubes out of a total $3880(0.3 \%)$ did not significantly affect condenser performance.

\section{No. 1 Feedwater Heater}

In March 1971 tube leakage in No. 1 feedwater heater was discovered when the shell side of the heater was observed to flood with water when isolated. Access to the tube bundle was obtained by removal of the shell. The three tubes found to be leaking were plugged at the tubesheet One of the tubes was removed for metallurgical examination. The wall thickness was nonuniform-- it varied from about 0.045 to 0.061 in. Failure of the tubes, made from admiralty brass, was due to stress-corrosion cracking ("season cracking") on the thin side of the tube, where the residual stresses caused by cold drawing in the tube fabrication were highest. This type of failure has been observed elsewhere on other units with admiralty-brass tubes.

Hydrazine, used at EBR-II to scavenge oxygen, can decompose to form ammonia. Hence, the failures were fudged to be due to stress-corrosion cracking promoted by ammonia. The possibility of such ammonia-promoted stress corrosion of copper-bearing alloys had been previously recognized. Injection of hydrazine (particularly during wet layup) has since been closely controlled to avoid excessive amounts, which would lead to increased ammonia concentrations. This procedure should greatly reduce the possibility of stress-corrosion cracking of copper-bearing alloys.

A routine leak test in September 1973 again revealed leakage in one tube in No. 1 feedwater heater. The tube was plugged without removing the heater shell for examination. Two additional tubco wcre found to be leaking and were plugged in September 1974. Six of a total of 124 tubes (5\%) in No. 1 feedwater heater have now been either plugged or removed. The 
performance of the heater has not been noticeably affected; however, because of the recurrence of tube failure, performance is being carefully monitored. If additional tube failures occur, procurement of a replacement. heater or tube bundle will be studied.

\section{F. Piping for 150-psig Steam}

Failures of two weld joints (original construction welds) in the piping for 150-psig steam were the only such failures in the steam system known to have caused unscheduled plant shutdowns.

The first failure (September 1973) was at a 3-in. branch connection into the 14-in. steam bypass pipe to the condenser. Failure was due primarily to inadequate flexibility of the piping arrangement, with defects in a poorly fabricated weld joint contributing. At the time of the failure, plans were already under way to modify the piping in a way that would eliminate the weld joint. However, it was expedient at the time to repair the joint and later complete the modification.

The second failure (January 1974) occurred in a 6-in. butt weld at a $6 \times 3$-in. reducing outlet tee. The 6-in. pipe is the heating-steam supply to the No. 2 feedwater heater. Failure was due to propagation of a crack originating from defects in the root pass of the weld joint. Propagation was due to large temperature transients that this foint is subject to during reactor startup and shutdown. The tee was repaired by improved welding techniques.

The modification that eliminated the first weld foint that failed was carried out in the spring of 1974. This modification, which was part of a system change that now supplies steam to the oil-fired auxiliary steam plant, eliminated piping components cunnecting the 150-psig steam system to the condenser. Elimination of this connection, which was used to direct excess 150psig steam to the condenser, was possible because the source of this steam was eliminated when the turbine-driver feedwater pump was removed and leakage was 
eliminated by replacement of the original 1250/150-psig pressure-reducing valve.

The piping remaining after removing the connection to the condenser was used in the modification to supply 150-psig steam to the auxiliary boiler plant. The new $1250 / 150$ psig control valve and a desuperheater, which was installed, reduce the pressure and temperature of the steam before it enters the auxiliary system. Supplying this steam saves up to $100 \mathrm{gph}$ of fuel oil during reactor power operation. Excess condensate from the auxiliary system is returned to the EBR-II condenser through filters and a demineralizer. To assure high quality of the returning water, it is monitored by conductivity meters. If the high quality is not maintained, a control valve closes automatically and thus stops flow of condensate back to the condenser.

\section{FUTURE IMPROVEMENTS}

Improvements are continuously being made to the EBR-II steam plant to improve safety, reliability, and ease of operation and to reduce cost and maintenance. Some additional improvements are important enough to warrant discussion.

EBR-II is normally maintained in a hot-standby condition when the reactor is shut down for refueling or maintenance. During this condition, periodic charging of the steam drum is required to maintain proper level. During a normal power outage, no pumping power is avallable for this charging. Installation of a small positive-displacement pump powered from the emergency power system is being considered to provide pumping power for this emergency. This pump would provide emergency charging of the steam drum during a normal power outage and be a hydrostatic test pump.

Operation of EBR-II without steam superheaters is being studied. A superheater-tube leak would require removing the superheater from service for replacement or repair. To allow operation of EBR-II soon after a superheater outage, the Project is preparing a contingency plan to bypass the superheaters 
and operate the plant with saturated steam.

The noise level in the power plant is very high when steam is bypassed directly to the condenser. Most of the noise originates from the bypass valve that throttles steam from 1250 to about 50 psig. Because of the excellent performance and low noise characteristics of the drag valve installed to control the deaerator steam supply, replacing the existing valve with a similar drag valve is being considered.

The feedwater-control system at EBR-II has two control valves: one for drum level and one on pump discharge. The one on pump discharge controls to maintain a constant pressure drop (about 75 psi) across the leve1control valve, which in turn maintains proper drum level. This two-level control system has led to system oscillations in feedwater flow rate and drum level. The excellent performance of the drag valve installed with the new motor-driven feedwater pump indicates that controlling the feedwater flow and drum level with one valve may be possible. A test is being planned to temporarily connect the drum-level controller to the control valve on the pump discharge. The valve that normally throttles to control drum level will be fully opened by manual control. If this test is successful, the method of feedwater control will be changed. Meanwhile, plans are in process to replace the valve controlling the discharge of feedwater pump No. 1 with a valve like that used with feedwater pump No. 2 .

\section{CONCLUSIONS}

The operating experfence of the EBR-II steam system has shown that:

1. There are no unusual or new problems in operating and maintaining a steam plant having an LMFBR as the energy source.

2. The EBR-II steam plant has been very reliable and seldom causes unscheduled reactor downtimes.

3. Close surveillance and a continuous program of maintenance and modification are required to maintain high availability. Modifying the plant 
to use newly developed equipment is most important for operation. Simplicity and ease of operation seem to benefit most from new developments.

4. Many modifications to the steam plant have been made because of the unique mission of the EBR-II reactor. Ease of startup and shutdown have been important because of the frequent shutdowns required by the refueling in conjunction with the irradiations program.

The EBR-II steam plant should continue to function as a reliable heat sink for the reactor plant. However, maintaining its high degree of availability requires a continuous active program of surveillance and maintenance. Early detection of potential problems is necessary so that corrective action may be taken before severe operating difficulties arise. An ample, readily available supply of spare parts is also required. This supply is becoming more important because of the increasingly longer lead time required by vendors to supply parts and equipment. 